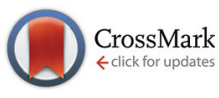

Cite this: Food Funct., 2016, 7, 2204

\title{
Chemical characterization and bioactive properties of Geranium molle L.: from the plant to the most active extract and its phytochemicals
}

\author{
V. C. Graça, ${ }^{a, b}$ Lillian Barros, ${ }^{b}$ Ricardo C. Calhelha, ${ }^{b}$ Maria Inês Dias, ${ }^{b}$ \\ Ana Maria Carvalho, ${ }^{b}$ Celestino Santos-Buelga, ${ }^{c}$ Isabel C. F. R. Ferreira*b and \\ P. F. Santos*d
}

\begin{abstract}
After a period of indifference, in which synthetic compounds were favored, there is an increasing interest in the study of the biological properties of plants and the active principles responsible for their therapeutic properties. Geranium molle L. has been used in the Portuguese folk medicine for the treatment of various ailments including cancer but, unlike many of the species from the Geranium genus, its phytochemical characterization and biological activity are virtually unexplored. In this study a G. molle sample from Trásos-Montes, north-eastern Portugal, was chemically characterized regarding nutritional value, free sugars, organic acids, fatty acids and tocopherols, and several aqueous (decoction, infusion) and organic ( $n$-hexane, dichloromethane, ethyl acetate, acetone, methanol) extracts of the plant were assessed for their bioactive properties. The antioxidant activity was evaluated by means of the free radicals scavenging activity, reducing power and inhibition of lipid peroxidation. The cytotoxicity of the different extracts was assessed in vitro against several human cancer cell lines (breast, lung, cervical and hepatocellular carcinomas) and, additionally, their hepatotoxicity was evaluated using a porcine liver primary cell culture. G. molle was shown to be rich in carbohydrates and proteins, providing tocopherols and essential fatty acids. Amongst the various extracts, the acetone extract was found to have the highest content of phenolic compounds (mainly ellagitannins, but also some flavone and flavonol glycosides) as well as the highest antioxidant and cytotoxic activities. To the best of our knowledge, this is the first report on the chemical composition and bioactive properties of $G$. molle.
\end{abstract}

Received 1st December 2015, Accepted 2nd April 2016

DOI: $10.1039 / c 5 f o 01479 d$

www.rsc.org/foodfunction
Geranium molle L., commonly known as Dove's-foot Crane's-bill or Dovesfoot Geranium, is an annual or biennial herb that belongs to the Geraniaceae family. This plant is native of Europe, northern Africa, and western Asia. It was introduced in southern Africa, the Americas, eastern Asia, Australia, and New Zealand. ${ }^{5,6}$ Geranium molle L. grows spontaneously in cultivated and waste places, open habitats, dunes, and dry grassland or roadsides, between 0 and $1500 \mathrm{~m}$ in altitude. $^{7,8}$

Unlike other species of the Geranium genus, namely the closely related Geranium robertianum L., there seems to be an almost complete absence of references to the use of Geranium molle in folk medicine. Exception is made to an ethnopharmacological study carried out by Neves et al. ${ }^{9}$ in some regions of Trás-os-Montes (north east Portugal), where the flowering aerial parts and roots of the wild plant are traditionally used to prepare decoctions and infusions for stomach acidity and stomach ache, gingivitis, eye inflammation and cuts, uterus inflammation and cancer treatment.

The phytochemistry of the Geranium genus is reasonably well-known and clearly dominated by phenolic constituents, ${ }^{10}$ 
the most studied classes of compounds being tannins, flavonoids and phenolic acids. The phenolic compounds, especially the flavonoids, have been cited as the main biologically active components among those found in Geranium species. ${ }^{11}$ This class of compounds from Geranium spp. were reported to exhibit antiviral, antitumor, antithrombotic, hepatoprotective, anti-inflammatory, antiallergic, antiproliferative, anticancer and immune stimulant effects. ${ }^{11-13}$

Although the Geranium genus phytochemistry is relatively well-known, reports on the chemical composition and biological properties of Geranium molle L. cannot be found in the literature. Therefore, in the present study, a wild sample of Geranium molle L. was analysed for its nutritional composition (proteins, fat, carbohydrates and ash) and chemically characterized regarding hydrophilic (sugars, organic acids) and lipophilic (fatty acids and tocopherols) molecules. An infusion and a decoction (common forms of consumption) and different organic extracts were evaluated for their bioactive properties, namely the antioxidant and antitumor properties, being the most active extract characterized in terms of phenolic compounds.

\section{Materials and methods}

\subsection{Standards and reagents}

Acetonitrile (99.9\%), $n$-hexane (97\%) and ethyl acetate (99.8\%) were of HPLC grade from Fisher Scientific (Lisbon, Portugal). The fatty acid methyl ester (FAME) reference standard mixture 37 (standard 47885-U) was purchased from Sigma (St Louis, MO, USA), as also, L-ascorbic acid, Trolox (6-hydroxy-2,5,7,8tetramethylchroman-2-carboxylic acid), organic acids, sugar standards, acetic acid, formic acid, ellipticine, sulphorhodamine B (SRB), trypan blue, trichloroacetic acid (TCA) and Tris. Phenolic compound standards were purchased from Extrasynthèse (Genay, France). Tocol $\left(50 \mathrm{mg} \mathrm{mL}^{-1}\right)$ and individual tocopherols were purchased from Matreya (Pleasant Gap, PA, USA). 2,2-Diphenyl-1-picrylhydrazyl (DPPH) was obtained from Alfa Aesar (Ward Hill, MA, USA). Foetal bovine serum (FBS), L-glutamine, Hank's balanced salt solution (HBSS), trypsinEDTA (ethylenediaminetetraacetic acid), penicillin/streptomycin solution (100 $\mathrm{U} \mathrm{mL}^{-1}$ and $100 \mathrm{mg} \mathrm{mL}^{-1}$, respectively), RPMI-1640 and DMEM media were from Hyclone (Logan, Utah, USA). Water was treated in a Milli-Q water purification system (TGI Pure Water Systems, Greenville, SC, USA).

\subsection{Plant material}

Geranium molle L. specimens in blossom (including thin roots, basal leaves, ascending stems, upper hairy leaves and flowers) were collected in Serra da Nogueira, Bragança, north-eastern Portugal, in March 2015, and subsequently, all dirt and dried parts were cleaned out. The amount of plant material collected was around $780 \mathrm{~g}$. Voucher specimens are deposited at the herbarium of the Escola Superior Agrária de Bragança (BRESA). The botanical identification was confirmed by the agronomist Dra. Ana Maria Carvalho of the School of Agriculture, Polytechnic Institute of Bragança (Trás-os-Montes, Portugal). The sample was lyophilized, reduced to a fine dried powder ( 20 mesh), mixed to obtain a homogeneous sample and stored in a refrigerator at $-20{ }^{\circ} \mathrm{C}$, protected from light.

\subsection{Chemical characterization}

2.3.1. Macronutrient composition of the crude plant material. The sample was analysed for its nutritional chemical composition (proteins, fat, carbohydrates and ash) through standard procedures. ${ }^{14}$ The crude protein content $(\mathrm{N} \times 6.25)$ of the sample was estimated by the macro-Kjeldahl method. The crude fat was determined by extracting a known weight of powdered sample with petroleum ether, using a Soxhlet apparatus. The ash content was determined by incineration at $600 \pm$ $15{ }^{\circ} \mathrm{C}$. Total carbohydrates were calculated by difference. Energy was calculated according to the following equation: energy $(\mathrm{kcal})=4 \times(\mathrm{g}$ protein $+\mathrm{g}$ carbohydrate $)+9 \times(\mathrm{g}$ fat $)$.

\subsubsection{Hydrophilic compounds}

Free sugars. Free sugars were determined via high performance liquid chromatography coupled to a refraction index detector (HPLC-RI), after an extraction procedure previously described by the authors ${ }^{15}$ using melezitose as internal standard (IS). The equipment consisted of an integrated system with a pump (Knauer, Smartline system 1000, Berlin, Germany), a degasser system (Smart line manager 5000) and an auto-sampler (AS-2057 Jasco, Easton, MD, USA) coupled to a refraction index (RI) detector (Knauer Smartline 2300). The chromatographic separation was achieved with a Eurospher 100-5 $\mathrm{NH}_{2}$ column $(5 \mu \mathrm{m}, 4.6 \times 250 \mathrm{~mm}$, Knauer) operating at $30{ }^{\circ} \mathrm{C}$ (7971 R Grace oven). The mobile phase was acetonitrile/ deionized water, $70: 30(\mathrm{v} / \mathrm{v})$, at a flow rate of $1 \mathrm{~mL} \mathrm{~min}^{-1}$. Sugar identification was performed by comparing the relative retention times of sample peaks with standards. Data were analyzed using Clarity 2.4 Software (DataApex, Podohradska, Czech Republic). Quantification was based on the RI signal response of each standard, using the IS (melezitose) method and by using the calibration curves obtained for the commercial standards of each compound. The results were expressed in $\mathrm{g}$ per $100 \mathrm{~g}$ of dry weight.

Organic acids. Organic acids were determined following a procedure previously optimized and described by the authors. ${ }^{16}$ The analysis was performed using a Shimadzu 20A series ultra-fast liquid chromatograph (UFLC) (Shimadzu Corporation, Kyoto, Japan). Separation was achieved on a SphereClone (Phenomenex, Torrance, CA, USA) reverse phase $\mathrm{C}_{18}$ column $(5 \mu \mathrm{m}, 4.6 \times 250 \mathrm{~mm})$ thermostatted at $35^{\circ} \mathrm{C}$. The elution was performed with $3.6 \mathrm{mM}$ sulphuric acid using a flow rate of $0.8 \mathrm{~mL} \mathrm{~min}^{-1}$. Detection was carried out with a diode array detector (DAD), using $215 \mathrm{~nm}$ and $245 \mathrm{~nm}$ (for ascorbic acid) as the preferred wavelengths. The organic acids found were quantified by comparison of the area of their peaks, recorded at 215 or $245 \mathrm{~nm}$, with the calibration curves obtained for commercial standards of each compound. The results were expressed in $\mathrm{g}$ per $100 \mathrm{~g}$ of dry weight. 


\subsubsection{Lipophilic compounds}

Fatty acids. Fatty acids were determined after transesterification according to the procedure previously described by the authors. ${ }^{15}$ The fatty acid profile was analyzed with a DANI 1000 gas chromatograph (GC) equipped with a split/splitless injector, a flame ionization detector (FID) and a MachereyNagel (Düren, Germany) column (50\% cyanopropyl-methyl$50 \%$ phenylmethylpolysiloxane, $30 \mathrm{~m} \times 0.32 \mathrm{~mm}$ i.d. $\times 0.25 \mu \mathrm{m}$ $\mathrm{d}_{\mathrm{f}}$ ). The oven temperature program was as follows: the initial temperature of the column was $50{ }^{\circ} \mathrm{C}$, held for $2 \mathrm{~min}$, then a $30{ }^{\circ} \mathrm{C}$ per min ramp to $125^{\circ} \mathrm{C}, 5^{\circ} \mathrm{C}$ per min ramp to $160{ }^{\circ} \mathrm{C}$, $20{ }^{\circ} \mathrm{C}$ per min ramp to $180{ }^{\circ} \mathrm{C}, 3{ }^{\circ} \mathrm{C}$ per min ramp to $200{ }^{\circ} \mathrm{C}$, $20^{\circ} \mathrm{C}$ per min ramp to $220^{\circ} \mathrm{C}$ and held for $15 \mathrm{~min}$. The carrier gas (hydrogen) flow-rate was $4.0 \mathrm{~mL} \min ^{-1}$ (0.61 bar), measured at $50{ }^{\circ} \mathrm{C}$. Split injection $(1: 40)$ was carried out at $250{ }^{\circ} \mathrm{C}$. Fatty acid identification was performed by comparing the relative retention times of the sample's FAME peaks with standards. The results were recorded and processed using Clarity 4.0.1.7 Software (DataApex, Podohradska, Czech Republic) and expressed as a relative percentage of each fatty acid.

Tocopherols. Tocopherols were determined following a procedure previously described by the authors. ${ }^{15}$ The analysis was performed by HPLC (equipment described in Section 2.3.2, sub section Free sugars), using a fluorescence detector (FP-2020; Jasco, Easton, MD, USA) programmed for excitation at $290 \mathrm{~nm}$ and emission at $330 \mathrm{~nm}$. The chromatographic separation was achieved with a Polyamide II (YMC Waters, Milford, MA, USA) normal-phase column (5 $\mu \mathrm{m}, 4.6 \mathrm{~mm} \times$ $250 \mathrm{~mm}$ ), operating at $35{ }^{\circ} \mathrm{C}$. The mobile phase used was a mixture of $n$-hexane and ethyl acetate $(70: 30, \mathrm{v} / \mathrm{v})$ at a flow rate of $1 \mathrm{~mL} \mathrm{~min}^{-1}$. The compounds were identified by chromatographic comparison with authentic standards. Quantification was based on the fluorescence signal response of each standard, using the IS (tocol) method, and the calibration curves obtained for commercial standards of each compound. The results were expressed in $\mathrm{mg}$ per $100 \mathrm{~g}$ of dry weight.

\subsection{Preparation of organic and aqueous extracts}

The organic (hexane, dichloromethane, ethyl acetate, acetone and methanol) and aqueous (obtained by infusion and decoction) extracts were prepared from the lyophilized plant.

For the preparation of the organic extracts a sample (100 g) was extracted with $500 \mathrm{~mL}$ of $n$-hexane and the mixture was stirred vigorously at room temperature, $150 \mathrm{rpm}$, for $48 \mathrm{~h}$, and then filtered under reduced pressure successively through a Whatman No. 541 paper and a sintered glass funnel. The solid residue was extracted with an additional $500 \mathrm{~mL}$ of $n$-hexane under the same conditions. The combined extracts were evaporated to dryness at $40{ }^{\circ} \mathrm{C}$ under reduced pressure. The resulting residue was further extracted sequentially with dichloromethane, ethyl acetate, acetone and finally methanol, according to the procedure described above.

The infusions were prepared by adding the sample $(1 \mathrm{~g})$ to $100 \mathrm{~mL}$ of boiling distilled water, left to stand at room temperature for $5 \mathrm{~min}$, and then filtered under reduced pressure successively through a Whatman No. 541 paper and a sintered glass funnel. The obtained infusions were frozen and lyophilized.

The decoctions were also prepared by adding the sample $(1 \mathrm{~g})$ to $100 \mathrm{~mL}$ of distilled water and boiled for $5 \mathrm{~min}$. The mixture was left to stand for $5 \mathrm{~min}$ at room temperature and then filtered under reduced pressure successively through a Whatman No. 541 paper and a sintered glass funnel. The obtained decoctions were frozen and lyophilized.

\subsection{Bioactive compounds in the extracts}

For total phenolics determination, an aliquot of the different extracts $\left(1 \mathrm{~mL}, 78-625 \mu \mathrm{g} \mathrm{mL}^{-1}\right)$ were mixed separately, with Folin-Ciocalteu reagent $(5 \mathrm{~mL}$, previously diluted with water $1: 10 \mathrm{v} / \mathrm{v})$ and sodium carbonate $\left(75 \mathrm{~g} \mathrm{~L}^{-1}, 4 \mathrm{~mL}\right)$. The tubes were vortexed for $15 \mathrm{~s}$ and allowed to stand for $30 \mathrm{~min}$ at $40{ }^{\circ} \mathrm{C}$ for color development. Absorbance was then measured at $765 \mathrm{~nm} .{ }^{17}$ Gallic acid was used to calculate the standard curve (0.1-1 $\mathrm{mM})$ and the results were expressed as $\mathrm{mg}$ of gallic acid equivalents (GAE) per $\mathrm{g}$ of extract.

For total flavonoids determination, an aliquot of the different extracts $\left(0.5 \mathrm{~mL}, 313-625 \mu \mathrm{g} \mathrm{mL}{ }^{-1}\right)$ were mixed separately, with distilled water $(2 \mathrm{~mL})$ and subsequently with $\mathrm{NaNO}_{2}$ solution $(5 \%, 0.15 \mathrm{~mL})$. After $6 \mathrm{~min}, \mathrm{AlCl}_{3}$ solution $(10 \%$, $0.15 \mathrm{~mL}$ ) was added and allowed to stand further $6 \mathrm{~min}$, thereafter, $\mathrm{NaOH}$ solution $(4 \%, 2 \mathrm{~mL})$ was added to the mixture. Immediately, distilled water was added to bring the final volume to $5 \mathrm{~mL}$. Then the mixture was mixed properly and allowed to stand for $15 \mathrm{~min}$. The intensity of the pink color was measured at $510 \mathrm{~nm} .{ }^{18}$ Catechin was used to calculate the standard curve $(0.3-1 \mathrm{mM})$ and the results were expressed as $\mathrm{mg}$ of catechin equivalents (CE) per $\mathrm{g}$ of extract.

\subsection{Evaluation of bioactive properties of the extracts}

2.6.1. Antioxidant activity assays. The organic extracts were redissolved in methanol (final concentration $10 \mathrm{mg} \mathrm{mL}{ }^{-1}$ ). The aqueous extracts were redissolved in water (final concentration $10 \mathrm{mg} \mathrm{mL}^{-1}$ ). The final solutions obtained were further diluted to different concentrations to be subjected to distinct evaluation assays of the antioxidant activity.

DPPH radical-scavenging activity was evaluated by using an ELX800 microplate reader (Bio-Tek Instruments, Inc.; Winooski, VT, USA), and calculated as a percentage of DPPH discoloration using the formula: $\left[\left(A_{\mathrm{DPPH}}-A_{\mathrm{S}}\right) / A_{\mathrm{DPPH}}\right] \times 100$, where $A_{\mathrm{S}}$ and $A_{\mathrm{DPPH}}$ are, respectively, the absorbance of the sample solution and that of the DPPH solution at $515 \mathrm{~nm}$. Reducing power was evaluated by the capacity to convert $\mathrm{Fe}^{3+}$ into $\mathrm{Fe}^{2+}$, measuring the absorbance at $690 \mathrm{~nm}$ in the microplate reader mentioned above. Inhibition of $\beta$-carotene bleaching was evaluated through the $\beta$-carotene/linoleate assay; the neutralization of linoleate free radicals avoids $\beta$-carotene bleaching, which is measured by the formula: ( $\beta$-carotene absorbance after $2 \mathrm{~h}$ of assay/initial absorbance) $\times 100$. Lipid peroxidation inhibition in porcine (Sus scrofa) brain homogenates was evaluated by the decrease in thiobarbituric acid reactive substances (TBARS); the color intensity of the 
malondialdehyde-thiobarbituric acid (MDA-TBA) was measured by its absorbance at $532 \mathrm{~nm}$; the inhibition ratio (\%) was calculated using the following formula: $[(A-B) / A] \times$ $100 \%$, where $A$ and $B$ are the absorbance of the control and the sample solution, respectively. ${ }^{16,19}$

The results were expressed in $\mathrm{EC}_{50}$ values (sample concentration providing $50 \%$ of antioxidant activity or 0.5 of absorbance in the reducing power assay). Trolox was used as positive control.

2.6.2. Cytotoxicity in human tumor cell lines. The aqueous and organic extracts were redissolved in water and ethanol $20 \%$, respectively, in order to obtain a final concentration of $8 \mathrm{mg} \mathrm{mL} \mathrm{m}^{-1}$. The final solution was further diluted to different concentrations ( 400 to $1.5 \mu \mathrm{g} \mathrm{mL}^{-1}$ ) to be subjected to in vitro cytotoxicity evaluation. Four human tumor cell lines were used: MCF-7 (breast adenocarcinoma), NCI-H460 (non-small cell lung cancer), HeLa (cervical carcinoma) and HepG2 (hepatocellular carcinoma). The cells were routinely maintained as adherent cell cultures in RPMI-1640 medium containing 10\% heat-inactivated FBS (MCF-7 and NCI-H460) and 2 mM glutamine or in DMEM supplemented with 10\% FBS, 2 mM glutamine, $100 \mathrm{U}$ per $\mathrm{mL}$ penicillin and $100 \mathrm{mg}$ per $\mathrm{mL}$ streptomycin (HeLa and HepG2 cells), at $37^{\circ} \mathrm{C}$, in a humidified air incubator containing $5 \% \mathrm{CO}_{2}$. Each cell line was plated at an appropriate density $\left(7.5 \times 10^{3}\right.$ cells per well for MCF-7 and NCI-H460 or $1.0 \times 10^{4}$ cells per well for HeLa and HepG2) in 96-well plates and allowed to attach for $24 \mathrm{~h}$. The cells were then treated for $48 \mathrm{~h}$ with the different diluted sample solutions. Following this incubation period, the adherent cells were fixed by adding cold $10 \%$ TCA $(100 \mu \mathrm{L})$ and incubated for $60 \mathrm{~min}$ at $4{ }^{\circ} \mathrm{C}$. Plates were then washed with deionized water and dried; SRB solution $(0.1 \%$ in $1 \%$ acetic acid, $100 \mu \mathrm{L})$ was then added to each plate-well and incubated for $30 \mathrm{~min}$ at room temperature. Unbound SRB was removed by washing with $1 \%$ acetic acid. Plates were air-dried, the bound SRB was solubilised with $10 \mathrm{mM}$ Tris $(200 \mu \mathrm{L}, \mathrm{pH} 7.4)$ and the absorbance was measured at $540 \mathrm{~nm}$ in the microplate reader mentioned above. ${ }^{16}$ The results were expressed in $\mathrm{GI}_{50}$ values (sample concentration that inhibited $50 \%$ of the net cell growth). Ellipticine was used as positive control.

2.6.3. Hepatotoxicity in non-tumor cells. A cell culture was prepared from a freshly harvested porcine liver obtained from a local slaughter house, and it was designed as PLP2. Briefly, the liver tissues were rinsed in Hank's balanced salt solution containing $100 \mathrm{U}$ per $\mathrm{mL}$ penicillin, $100 \mu \mathrm{g}$ per $\mathrm{mL}$ streptomycin and divided into $1 \times 1 \mathrm{~mm}^{3}$ explants. Some of these explants were placed in $25 \mathrm{~cm}^{2}$ tissue flasks in DMEM medium supplemented with $10 \%$ fetal bovine serum, $2 \mathrm{mM}$ nonessential amino acids and $100 \mathrm{U}$ per $\mathrm{mL}$ penicillin, $100 \mathrm{mg}$ per $\mathrm{mL}$ streptomycin and incubated at $37{ }^{\circ} \mathrm{C}$ under a humidified atmosphere containing $5 \% \quad \mathrm{CO}_{2}$. The medium was changed every two days. Cultivation of the cells was continued with direct monitoring every two to three days using a phase contrast microscope. Before confluence was reached, cells were subcultured and plated in 96-well plates at a density of $1.0 \times$ $10^{4}$ cells per well, and cultivated in DMEM medium with $10 \%$
FBS, $100 \mathrm{U}$ per $\mathrm{mL}$ penicillin and $100 \mu \mathrm{g}$ per $\mathrm{mL}$ streptomycin. ${ }^{15,16}$ Cells were treated for $48 \mathrm{~h}$ with the different diluted sample solutions and the same procedure described in the previous section for the SRB assay was followed. The results were expressed in $\mathrm{GI}_{50}$ values (sample concentration that inhibited $50 \%$ of the net cell growth). Ellipticine was used as positive control.

\subsection{Phenolic composition of the acetone extract}

The acetone extract was redissolved in water/methanol $80: 20$ (v/v) (final concentration $5 \mathrm{mg} \mathrm{mL}^{-1}$ ). Phenolic compounds were determined by HPLC (Hewlett-Packard 1100 chromatographer, Agilent Technologies, Santa Clara, CA, USA) as previously described by the authors. ${ }^{16,19}$ Double online detection was carried out with a DAD using $280 \mathrm{~nm}$ and $370 \mathrm{~nm}$ as preferred wavelengths and with a mass spectrometer (MS) connected to the HPLC system via the DAD cell outlet. The phenolic compounds were identified by comparing their retention time, UVvis and mass spectra with those obtained from standard compounds, when available. Otherwise, peaks were tentatively identified comparing the obtained information with the available data reported in the literature. For quantitative analysis, a calibration curve for each available phenolic standard was constructed based on the UV signal. For the identified phenolic compounds for which a commercial standard was not available, the quantification was performed through the calibration curve of other compound from the same phenolic group. The results were expressed in $\mathrm{mg}$ per $\mathrm{g}$ of extract.

\subsection{Statistical analysis}

For all the experiments, three samples were analyzed and all the assays were carried out in triplicate. The results are expressed as mean values \pm standard deviation (SD). The differences between the different samples were analyzed using oneway analysis of variance (ANOVA) followed by Tukey's honestly significant difference post hoc test with $\alpha=0.05$, coupled with Welch's statistic. This treatment was carried out using the SPSS v. 22.0 program.

\section{Results and discussion}

\subsection{Chemical characterization of Geranium molle $\mathrm{L}$.}

The results of the nutritional characterization of G. molle, namely, macronutrients, sugars, organic acids and fatty acids, are presented in Table 1. Carbohydrates were the most abundant macronutrients found in the studied sample, followed by proteins, fat and ash. This plant showed $72.2 \%$ of moisture and the energetic contribution was $\sim 436 \mathrm{kcal}$ per $100 \mathrm{~g} \mathrm{dw}$.

Fructose, glucose and sucrose were the free sugars detected in this sample. The total sugar content was $\sim 9 \mathrm{~g}$ per $100 \mathrm{~g} \mathrm{dw}$, glucose being present in a much larger amount ( $6 \mathrm{~g}$ per $100 \mathrm{~g} \mathrm{dw}$ ) than the two other sugars.

A total of six different organic acids were detected in the plant, namely, oxalic, quinic, malic, ascorbic, citric and fumaric acids (Table 1). Malic acid was the most abundant 
Table 1 Chemical characterization of Geranium molle L. in terms of macronutrients, and hydrophilic and lipophilic compounds

\begin{tabular}{|c|c|c|c|}
\hline & Quantity & & Quantity \\
\hline Moisture (g per $100 \mathrm{~g}$ fw) & $72.2 \pm 0.3$ & $\mathrm{C} 15: 0$ & $0.95 \pm 0.01$ \\
\hline Proteins (g per $100 \mathrm{~g}$ dw) & $20.9 \pm 0.4$ & C16:1 & $0.69 \pm 0.01$ \\
\hline Ash (g per $100 \mathrm{~g} \mathrm{dw})$ & $10.5 \pm 0.1$ & C17:0 & $1.21 \pm 0.01$ \\
\hline Carbohydrates (g per $100 \mathrm{~g}$ dw) & $53.1 \pm 0.2$ & C18:0 & $17.2 \pm 0.2$ \\
\hline Energy (kcal per $100 \mathrm{~g} \mathrm{dw}$ ) & $436 \pm 2$ & C18:1n9 & $26.1 \pm 0.1$ \\
\hline Fructose & $1.62 \pm 0.01$ & $\mathrm{C} 20: 0$ & $0.72 \pm 0.02$ \\
\hline Glucose & $6.32 \pm 0.01$ & $\mathrm{C} 20: 1$ & $0.08 \pm 0.01$ \\
\hline Sucrose & $0.99 \pm 0.01$ & $\mathrm{C} 20: 2$ & $0.034 \pm 0.002$ \\
\hline Sum of sugars (g per $100 \mathrm{~g} \mathrm{dw}$ ) & $8.93 \pm 0.02$ & $\mathrm{C} 20: 3 \mathrm{n} 6$ & $0.08 \pm 0.01$ \\
\hline Oxalic acid & $0.71 \pm 0.01$ & $\mathrm{C} 20: 4 \mathrm{n} 6$ & $0.39 \pm 0.01$ \\
\hline Quinic acid & $2.6 \pm 0.3$ & $\mathrm{C} 20: 3 \mathrm{n} 3+\mathrm{C} 21: 0$ & $0.18 \pm 0.01$ \\
\hline & & C24:1 & $0.043 \pm 0.001$ \\
\hline Lipophilic compounds & & SFA $(\%)$ & $61.64 \pm 0.18$ \\
\hline C6:0 & $2.11 \pm 0.01$ & MUFA (\%) & $27.12 \pm 0.09$ \\
\hline C8:0 & $1.39 \pm 0.01$ & PUFA (\%) & $11.24 \pm 0.08$ \\
\hline C10:0 & $3.35 \pm 0.01$ & $\alpha$-Tocopherol & $18.9 \pm 0.6$ \\
\hline C11:0 & $0.022 \pm 0.001$ & $\beta$-Tocopherol & $0.33 \pm 0.01$ \\
\hline C12:0 & $1.98 \pm 0.01$ & $\gamma$-Tocopherol & $0.76 \pm 0.01$ \\
\hline C13:0 & $0.063 \pm 0.004$ & Sum of tocopherols (mg per $100 \mathrm{~g} \mathrm{dw}$ ) & $19.99 \pm 0.55$ \\
\hline C14:0 & $7.39 \pm 0.01$ & & \\
\hline
\end{tabular}

(C6:0), caproic acid; (C8:0), caprylic acid; (C10:0), capric acid; (C11:0), undecylic acid; (C12:0), lauric acid; (C13:0), tridecanoic acid; (C14:0), myristic acid; (C14:1), myristoleic acid; (C15:0), pentadecanoic acid; (C16:0), palmitic acid; (C16:1), palmitoleic acid; (C17:0), heptadecanoic acid; (C18:0), stearic acid; (C18:1n9c+t), oleic acid; (C18:2n6c), linoleic acid; (C18:3n3), $\alpha$-linolenic acid; (C20:0), arachidic acid; (C20:1), cis-11eicosenoic acid; (C20:2), cis-11,14-Eicosadienoic acid; (C20:3n6), eicosatrienoic acid; (C20:4n6), arachidonic acid; (C20:3n3 + C21:0), cis-11,14,17eicosatrienoic acid and heneicosanoic acid; (C20:5n3), eicosapentaenoic acid; (C22:0), behenic acid; (C22:1n9), Erucic acid; (C22:6n3), docosahexaenoic acid; (C24:0), lignoceric acid; (C24:1), nervonic acid; SFA - saturated fatty acids; MUFA - monounsaturated fatty acids; PUFA polyunsaturated fatty acids; fw - fresh weight; dw - dry weight.

$(\sim 2.8 \mathrm{~g}$ per $100 \mathrm{~g} \mathrm{dw})$, followed by quinic acid $(\sim 2.6 \mathrm{~g}$ per $100 \mathrm{~g} \mathrm{dw})$.

Twenty-eight fatty acids (FA) were determined in G. molle (Table 1). Highest percentages were found for oleic (C18:1n9), palmitic (C16:0) and stearic acids (C18:0). Saturated fatty acids (SFA) predominated over monounsaturated fatty acids (MUFA) and polyunsaturated fatty acids (PUFA).

Regarding tocopherols, $\alpha$-tocopherol (18.9 mg per $100 \mathrm{~g} \mathrm{dw}$ ) was the most abundant isoform present in G. molle. $\beta$-Tocopherol and $\gamma$-tocopherol were present but in very small amounts. $\delta$-Tocopherol was not detected in this plant.

\subsection{Bioactive compounds in different Geranium molle L. extracts}

Concentrations of total polyphenols and total flavonoids, as determined by photometrical methods in different G. molle extracts are presented in Table 2. The acetone extract displayed the highest content of both total polyphenols (497 mg GAE per $\mathrm{g}$ extract) and total flavonoids (112 $\mathrm{mg} \mathrm{CE}$ per $\mathrm{g}$ extract). Acetone has been reported as a good solvent for the extraction of phenolic compounds and flavonoids. ${ }^{20,21}$ The infusion and the decoction presented similar concentrations of total flavo- noids but somewhat different content of total polyphenols, the extract resulting from the infusion being richer in this group of compounds. The dichloromethane and the $n$-hexane extracts showed very low concentrations of both total polyphenols and total flavonoids.

\subsection{Bioactive properties of different Geranium molle L. extracts}

The in vitro antioxidant and cytotoxic properties of different extracts of $G$. molle were evaluated, and the results are presented in Table 3. The antioxidant activity was determined by free radical (DPPH) scavenging activity, reducing power, inhibition of lipid peroxidation in brain cell homogenates, and TBARS assays. The cytotoxicity was tested against human tumor cell lines (breast, lung, cervical and hepatocellular carcinomas) and the hepatotoxicity was evaluated using a porcine liver primary cell culture.

In general, all the extracts revealed antioxidant potential. The acetone extract displayed the highest antioxidant activity in all the assays. This was probably related to the higher content of total phenols and total flavonoids found in this extract, compared to the other prepared extracts (Table 2). The 
Table 2 Bioactive compounds in different Geranium molle L. extracts

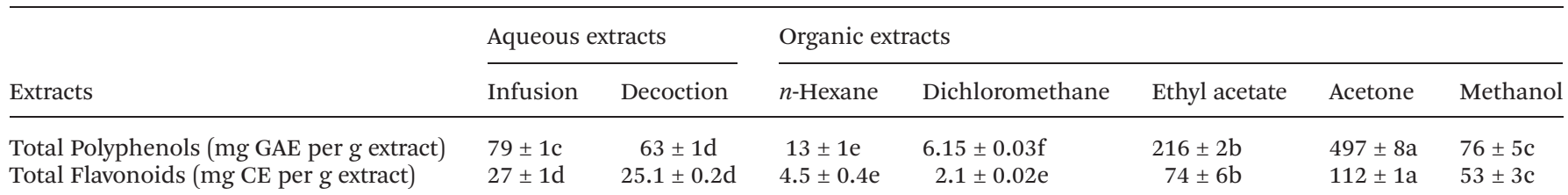

GAE - gallic acid equivalents; CE - catechin equivalents. In each row different letters mean significant differences $(p<0.05)$.

Table 3 Bioactive properties of different Geranium molle L. extracts

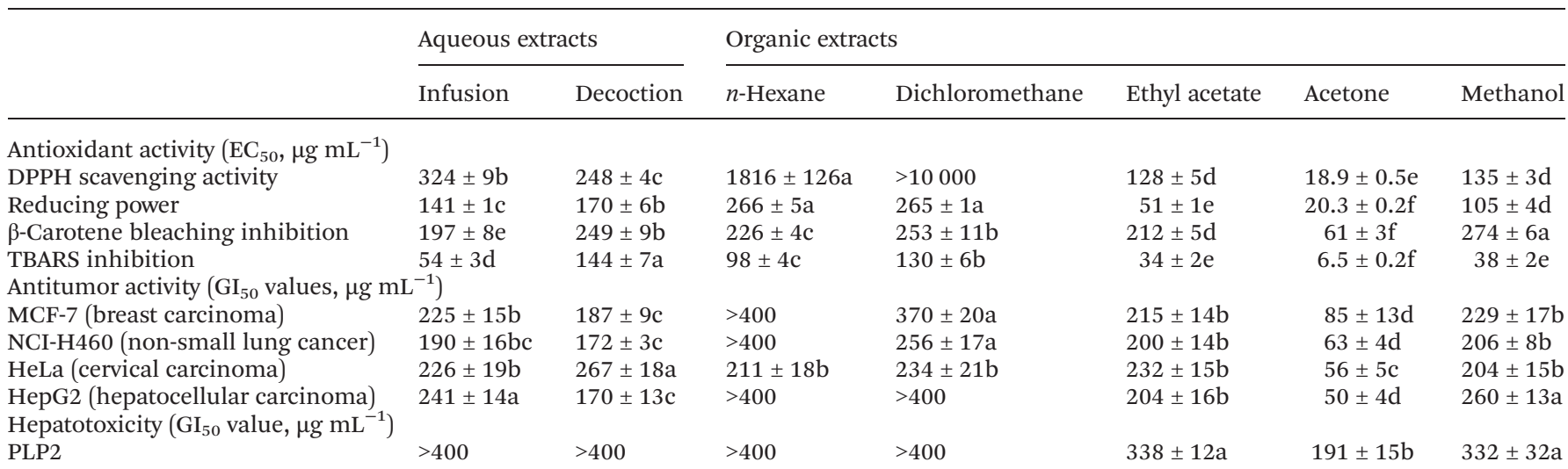

The antioxidant activity was expressed as $\mathrm{EC}_{50}$ values, which means that higher values correspond to lower reducing power or antioxidant potential. $\mathrm{EC}_{50}$ : extract concentration corresponding to $50 \%$ of antioxidant activity or 0.5 of absorbance in reducing power assay. Trolox $\mathrm{EC}_{50}$ values: $41 \mu \mathrm{g} \mathrm{mL} L^{-1}$ (reducing power), $42 \mu \mathrm{g} \mathrm{mL} \mathrm{L}^{-1}$ (DPPH scavenging activity), $18 \mu \mathrm{g} \mathrm{mL} \mathrm{m}^{-1}$ ( $\beta$-carotene bleaching inhibition) and $23 \mu \mathrm{g} \mathrm{mL}{ }^{-1}$ (TBARS inhibition). $\mathrm{GI}_{50}$ values correspond to the sample concentration achieving $50 \%$ of growth inhibition in human tumour cell lines or in liver primary culture PLP2. Ellipticine GI 50 values: $1.21 \mu \mathrm{g} \mathrm{mL} \mathrm{m}^{-1}$ (MCF-7), $1.03 \mu \mathrm{g} \mathrm{mL} \mathrm{mL}^{-1}$ (NCI-H460), $0.91 \mu \mathrm{g} \mathrm{mL}^{-1}$ (HeLa), $1.10 \mu \mathrm{g} \mathrm{mL}{ }^{-1}$ (HepG2) and $2.29 \mu \mathrm{g} \mathrm{mL} \mathrm{m}^{-1}$ (PLP2). In each row different letters mean significant differences $(p<0.05)$.

antioxidant properties of many plants are closely related to the presence of phenolic compounds, which constitute the most abundant secondary metabolites of plants. ${ }^{22}$

Regarding the cytotoxic properties, almost all of the extracts showed activity. The aqueous extract obtained by infusion, and methanol and ethyl acetate extracts showed similar cytotoxic effects against MCF-7, NCI-H460 and HeLa cells. The dichloromethane extract was ineffective against the HepG2 cell line even at the maximum concentration assayed $\left(400 \mu \mathrm{g} \mathrm{mL} \mathrm{m}^{-1}\right)$. The $n$-hexane extract showed activity only against HeLa cells. The acetone extract displayed the highest cytotoxic effect, being significantly more potent than the remaining extracts $\left(\mathrm{GI}_{50}\right.$ values approximately four times lower) against all cell lines. Unfortunately, this extract also presented the highest toxicity against normal primary cells from the porcine liver (PLP2) $\left(\mathrm{GI}_{50} \sim 190 \mu \mathrm{g} \mathrm{mL}^{-1}\right)$. However, the concentration required to reach $50 \%$ of growth inhibition of PLP2 is about 3-4 times higher than the concentration required to achieve $50 \%$ of growth inhibition of the human tumor cell lines tested.

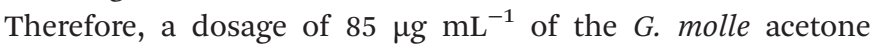
extract would be recommended to guarantee $50 \%$ of growth inhibition of the human tumor cell lines tested, without presenting toxicity effects for non-tumor cells.
The aqueous, dichloromethane and $n$-hexane extracts did not show hepatotoxicity against PLP2 cells up to the maximal tested concentration $\left(\mathrm{GI}_{50}>400 \mu \mathrm{g} \mathrm{mL} \mathrm{L}^{-1}\right)$. The methanol and ethyl acetate extracts presented similar hepatotoxicity against this cell line $\left(\mathrm{GI}_{50} \sim 330 \mu \mathrm{g} \mathrm{mL}^{-1}\right)$.

Trolox and ellipticine were used as positive controls in the antioxidant and cytotoxic activity assays, respectively. However, as these are individual compounds, they should not be considered as standards and comparison with the results obtained for the extracts/oral preparations should be avoided since an eventual synergistic effect of the mixtures cannot be precluded.

\subsection{Analysis of phenolic compounds in the acetone extract}

Amongst the several G. molle extracts prepared, the acetone extract was found to exhibit the highest amount of total phenolic compounds, as well as the highest antioxidant and cytotoxic activity, so that its detailed phenolic composition was also analysed. The HPLC phenolic profile of that extract recorded at 280 and $370 \mathrm{~nm}$ is shown in Fig. 1. The peak characteristics and tentative identities are presented in Table 4. Sixteen phenolic compounds were detected, five of which were ellagitannins, one phenolic acid and ten flavonoids. 


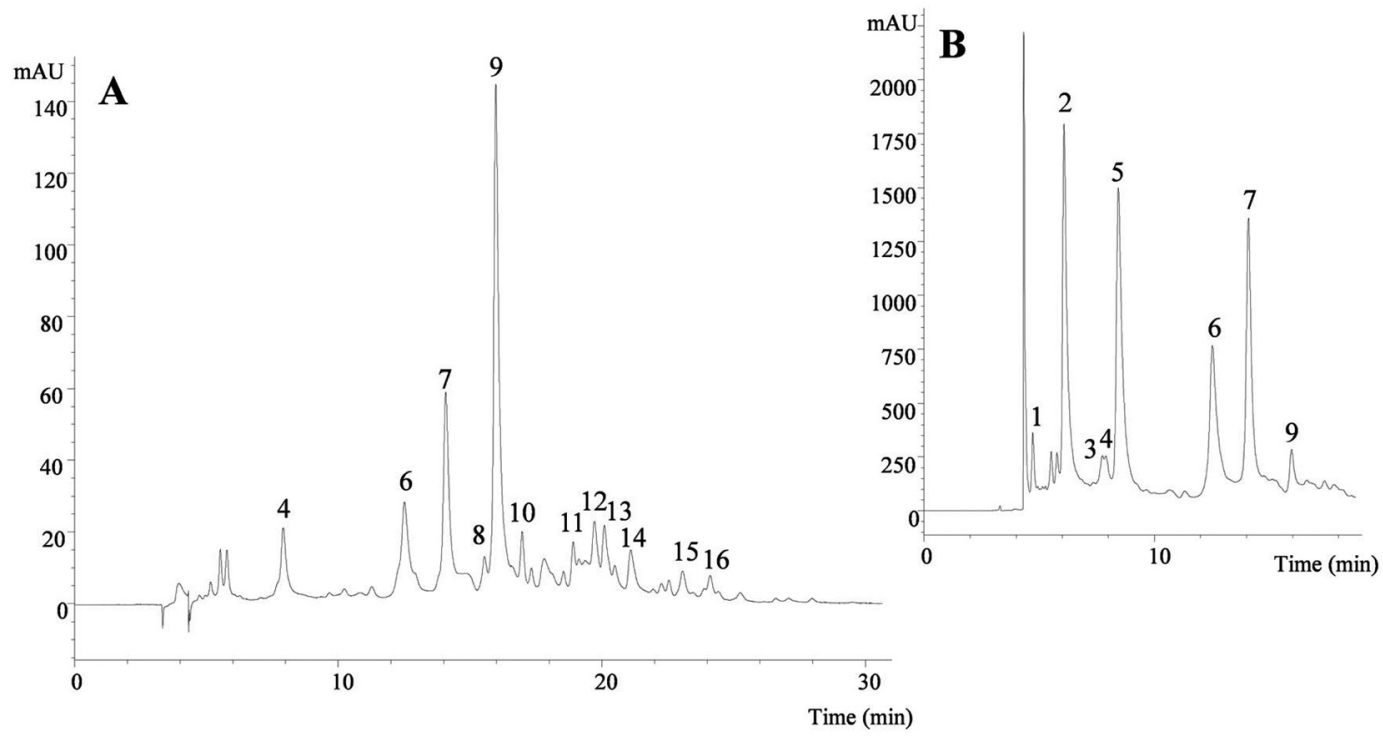

Fig. 1 Phenolic profile of Geranium molle L. acetone extract recorded at $370 \mathrm{~nm}(\mathrm{~A})$ and $280 \mathrm{~nm}(\mathrm{~B})$.

Table 4 Retention time $\left(R_{\mathrm{t}}\right)$, wavelengths of maximum absorption in the visible region $\left(\lambda_{\text {max }}\right)$, mass spectral data, identification and quantification of phenolic compounds of the acetone extract of Geranium molle L.

\begin{tabular}{|c|c|c|c|c|c|c|}
\hline Peak & $\begin{array}{l}R_{\mathrm{t}} \\
(\min )\end{array}$ & $\begin{array}{l}\lambda_{\max } \\
(\mathrm{nm})\end{array}$ & $\begin{array}{l}\text { Molecular ion } \\
{[\mathbf{M}-\mathbf{H}]^{-}(m / z)}\end{array}$ & $\mathbf{M S}^{2}(m / z)$ & Tentative identification & $\begin{array}{l}\text { Quantification } \\
\left(\mathrm{mg} \mathrm{g}^{-1}\right)\end{array}$ \\
\hline 1 & 4.7 & 278 & 633 & 463(5), 421(3), 301(82), 275(49), 169(8) & Galloyl-HHDP-glucose & $4.8 \pm 0.1$ \\
\hline 3 & 7.7 & 278 & 289 & $245(40), 203(30), 187(40), 161(30), 137(20)$ & $(+)$-Catechin & $16 \pm 1$ \\
\hline 4 & 7.9 & 328 & 353 & 191(100), 179(47), 173(39), 161(20), 135(25) & 5-O-Caffeoylquinic acid & $7 \pm 1$ \\
\hline 5 & 8.4 & 276 & 785 & 633(6), 615(8), 483(20), 301(77), 275(28), 169(8) & Digalloyl-HHDP-glucose & $66 \pm 5$ \\
\hline 6 & 12.5 & 276 & 783 & 765(77), 721(5), 481(5), 301(13), 275(17) & Bis-HHDP-glucose & $43 \pm 3$ \\
\hline 9 & 16.0 & 350 & 447 & 429(15), 357(90), 327(80), 297(50), 285(21) & Luteolin-6-C-glucoside & $4.7 \pm 0.3$ \\
\hline 10 & 17.0 & 358 & 609 & $301(100)$ & Quercetin-3-O-rutinoside & $0.37 \pm 0.03$ \\
\hline 11 & 18.9 & 340 & 563 & 443(17), 413(33), 311(67), 293(33) & Apigenin 2"-O-pentosyl-6-C-hexoside & $0.69 \pm 0.04$ \\
\hline 12 & 19.7 & 336 & 431 & 413(5), 341(40), 311(100), 283(53) & Apigenin-6- $C$-glucoside & $1.53 \pm 0.10$ \\
\hline 13 & 20.1 & 358 & 463 & $301(100)$ & Quercetin-3-O-glucoside & $0.60 \pm 0.02$ \\
\hline 14 & 21.1 & 354 & 593 & $285(100)$ & Kaempferol-3-O-rutinoside & $0.89 \pm 0.01$ \\
\hline 15 & 23.1 & 356 & 433 & $301(100)$ & Quercetin-O-pentoside & $0.20 \pm 0.02$ \\
\hline & & & & & Total phenolic compounds & $265 \pm 19$ \\
\hline
\end{tabular}

$(+)$-Catechin (compound 3), 5-O-caffeoylquinic acid (compound 4), luteolin-6-C-glucoside (compound 9), quercetin-3-Orutinoside (compound 10), apigenin-6-C-glucoside (compound 12), quercetin-3-O-glucoside (compound 13), kaempferol-3-Orutinoside (compound 14) and kaempferol-3-O-glucoside (compound 16) were positively identified according to their retention, mass and UV-vis characteristics by comparison with commercial standards.

Compounds 1, 2 and 5-7 were identified as hydrolysable tannins (ellagitannin derivatives) and assigned as different hexahydroxydiphenoyl (HHDP)-glucose esters based on their pseudomolecular ions and fragmentation patterns. Thus, the mass characteristics of compound $\mathbf{1}\left([\mathrm{M}-\mathrm{H}]^{-}\right.$at $\mathrm{m} / \mathrm{z}$ 633) pointed to a galloyl-HHDP-glucose isomer, whereas those of compounds 2 and $5\left([\mathrm{M}-\mathbf{H}]^{-}\right.$at $\left.m / z 785\right)$ were consistent with digalloyl-HHDP-glucose isomers, and compounds 6 and 7 with bis-HHDP-glucose isomers. ${ }^{23,24}$ Similar compounds have been described in other Geranium species; $;^{10,25-31}$ actually HHDP esters are considered as the main hydrolysable tannins and majority phenolic compounds in most species of Geranium. ${ }^{10,25,27,32,33}$ However, to the best of our knowledge, they have never been reported in G. molle.

The remaining compounds would correspond to flavonoids. Compounds $8\left([\mathrm{M}-\mathrm{H}]^{-}\right.$at $\left.m / z 755\right)$ and $\mathbf{1 5}\left([\mathrm{M}-\mathrm{H}]^{-}\right.$at $\mathrm{m} / \mathrm{z}$ 
447) were associated to quercetin glycosides based on their absorption spectra and the production of an ion fragment at $\mathrm{m} / \mathrm{z}$ 301. Their molecular weights pointed to a quercetin- $O$ pentoside (peak 15) and a quercetin derivative bearing two deoxyhexosyl and one hexosyl residues (peak 8). In the latter derivative, the fact that only one $\mathrm{MS}^{2}$ fragment was released corresponding to the aglycone suggests that the three sugars constituted a trisaccharide. Flavonol derivatives have been previously described in other Geranium sp. pl., namely different quercetin and kaempferol aglycones and glycoside derivatives. $^{34-40}$

Finally compound $11\left([\mathrm{M}-\mathrm{H}]^{-}\right.$at $\left.m / z 563\right)$ was tentatively assigned as apigenin 2"-O-pentosyl-6- $C$-hexoside according to its pseudomolecular ion and fragmentation pattern. A compound with the same characteristics had been previously found by our group in Arenaria montana ${ }^{41}$ and identified based on the fragmentation patterns described by Ferreres et $a l^{42}$ and Ferreres et $a l^{43}$ for $O, C$-glycosyl flavones. As far as we know this type of compound is reported herein for the first time in Geranium species, although some flavone $O$-glycosides and aglycones, i.e., luteolin and apigenin, have been reported in Geranium sp. pl. ${ }^{35,38-40}$

Digalloyl-HHDP-glucoside (compound 5) was the most abundant ellagitannin present, while luteolin-6- $C$-glucoside (compound 9) was the best represented flavonoid. Chlorogenic acid (i.e., 5-O-caffeoylquinic acid) was the only hydroxycinnamoyl derivative found in the analysed sample.

\section{Conclusions}

Geranium molle L. is rich in carbohydrates and proteins, providing tocopherols and essential fatty acids. In general, the various aqueous and organic extracts showed antioxidant activity and cytotoxicity against the different human tumour cell lines tested. The acetone extract presented the highest antioxidant potential in the different assays, which is most probably related to its higher content of polyphenols and flavonoids compared with the other prepared extracts. The acetone extract also displayed the highest cytotoxic effect, being significantly more potent than the remaining extracts against all cell lines $\left(\mathrm{GI}_{50}\right.$ values approximately four times lower). Although this extract also presented the highest toxicity against porcine liver primary cells (PLP2), the $\mathrm{GI}_{50}$ value for PLP2 was about 3-4 times higher than those for the tumor cell lines tested. The decoction and the infusion of the plant, which are the common forms of folk consumption, did not show hepatotoxicity against PLP2 cells up to the maximal tested concentration $\left(400 \mu \mathrm{g} \mathrm{mL}{ }^{-1}\right)$, but presented $\mathrm{GI}_{50}$ for the tumor cells 3-4 times higher than the acetone extract. The phenolic profile of the acetone extract was determined by HPLC-MS and shown to be constituted mainly by ellagitannins, as well as some flavone and flavonol glycosides. All in all, the obtained results support the folk medicinal use of G. molle, and its interest as a source of phytochemicals with bioactive properties to be explored in the medicine and food industries.

\section{Acknowledgements}

This work is supported by national funds by FCT - Portuguese Foundation for Science and Technology, under the project UID/AGR/04033/2013 and PEst-OE/AGR/UI0690/2014. V. C. Graça, M. I. Dias, R. C. Calhelha and L. Barros thank FCT for SFRH/BD/52542/2014, SFRH/BD/84485/2012, SFRH/BPD/ $68344 / 2010$ and SFRH/BPD/107855/2015 grants, respectively.

\section{References}

1 J. Camejo-Rodrigues, L. Ascensão, A. M. Bonet and J. Vallès, J. Ethnopharmacol., 2003, 89, 199-209.

2 J. L. Longe, The Gale Encyclopedia of Alternative Medicine, Thomson Gale, Farmington Hills, 2nd edn, 2005.

3 N. C. C. Silva and A. Fernandes-Júnior, J. Venom. Anim. Toxins incl. Trop. Dis., 2010, 16, 402-413.

4 L. Rubió, M.-J. Motilva and M.-P. Romero, Crit. Rev. Food Sci. Nutr., 2013, 53, 943-953.

5 C. Aedo, J. J. Aldasoro and C. Navarro, Ann. Missouri Bot. Gard., 1998, 85, 594-630.

6 C. Aedo, F. M. Garmendia and F. Pando, Anales Jard. Bot. Madrid, 1998, 56, 211-252.

7 S. Pignatti, Flora d'Italia - Edagricole, 1982, vol. II, p. 10.

8 C. Aedo, Anales Jard. Bot. Madrid, 2000, 58, 39-82.

9 J. M. Neves, C. Matos, C. Moutinho, G. Queiroz and L. R. Gomes, J. Ethnopharmacol., 2009, 124, 270-283.

$10 \mathrm{~J}$. B. Harborne and C. A. Williams, in Geranium and Pelargonium - The genera Geranium and Pelargonium, ed. M. Lis-Balchin, Taylor \& Francis, New York, 2002, vol. 4, pp. 20-29.

11 E. Neagu, G. P. Roman, G. L. Radu and G. Nechifor, Rom. Biotechnol. Lett., 2010, 15, 5042-5048.

12 A. Saija, M. Scalase, M. Lanza, D. Marzulla, F. Bonina and F. Castelli, Free Radical Biol. Med., 1995, 19, 481-486.

13 J.-U. Shim, P.-S. Oha and K.-T. Limb, J. Ethnopharmacol., 2009, 126, 90-95.

14 AOAC, Official methods of analysis, Association of Official Analytical Chemists Gaithersburg, Maryland, 18th edn, 2005.

15 L. Barros, E. Pereira, R. C. Calhelha, M. Dueñas, A. M. Carvalho, C. Santos-Buelga and I. C. F. R. Ferreira, J. Funct. Foods, 2013, 5, 1732-1740.

16 M. I. Dias, L. Barros, M. Dueñas, E. Pereira, A. M. Carvalho, R. C. Alves, M. B. P. P. Oliveira, C. Santos-Buelga and I. C. F. R. Ferreira, Food Chem., 2013, 141, 4152-4160.

17 V. L. Singleton, R. Orthofer and R. M. Lamuela-Raventos, Methods Enzymol., 1999, 299, 152-178.

18 J. Zhishen, T. Mengcheng and W. Jianming, Food Chem., 1999, 64, 555-559.

19 C. L. Roriz, L. Barros, A. M. Carvalho, C. Santos-Buelga and I. C. F. R. Ferreira, Food Res. Int., 2014, 62, 684-693.

20 L. Barros, M. Dueñas, I. C. F. R. Ferreira, P. Baptista and C. Santos-Buelga, Food Chem. Toxicol., 2009, 47, 1076-1079. 
21 J. Azmir, I. S. M. Zaidul, M. M. Rahman, K. M. Sharif, A. Mohamed, F. Sahena, M. H. A. Jahurul, K. Ghafoor, N. A. N. Norulaini and A. K. M. Omar, J. Food Eng., 2013, 117, 426-436.

22 J. Dai and R. J. Mumper, Molecules, 2010, 15, 7313-7352.

23 P. Mena, L. Calani, C. Dall'Asta, G. Galaverna, C. GarcíaViguera, R. Bruni, A. Crozier and D. Del Rio, Molecules, 2012, 17, 14821-14840.

24 J. Regueiro, C. Sánchez-González, A. Vallverdú-Queralt, J. Simal-Gándara, R. Lamuela-Raventós and M. IzquierdoPulido, Food Chem., 2014, 152, 340-348.

25 E. C. Bate-Smith, Phytochemistry, 1972, 11, 1755-1757.

26 T. Okuda, K. Mori, K. Seno and T. Hatano, J. Chromatogr., 1979, 171, 313-320.

27 E. C. Bate-Smith, Phytochemistry, 1981, 20, 211-216.

28 T. Okuda, T. Yoshida and T. Hatano, Phytochemistry, 2000, 55, 513-529.

29 T. Okuda, Phytochemistry, 2005, 66, 2012-2031.

30 A. Tuominen, Phytochemistry, 2013, 95, 408-420.

31 A. Tuominen, E. Toivonen, P. Mutikainen and J.-P. Salminen, Phytochemistry, 2013, 95, 394-407.

32 T. Okuda, K. Mori and T. Hatano, Phytochemistry, 1980, 19, 547-551.

33 Q.-Y. Wu, Y. Zhou, X. Jin, Y. Guan, M. Xu and L.-F. Liu, Int. J. Mol. Sci., 2011, 12, 8740-8749.
34 T. Kartnig and J. Bucar-Stachel, Planta Med., 1991, 57, 292293.

35 S. Ivancheva and A. Petrova, Biochem. Syst. Ecol., 2000, 28, 255-260.

36 K. B. Kobakhidze and M. D. Alaniya, Chem. Nat. Compd., 2004, 40, 89-90.

37 C. S. Fodorea, L. Vlase, S. Suciu, M. Tamas and S. E. Leucuta, Rev. Med. Chir. Soc. Med. Nat. Iasi, 2005, 109, 174-178.

38 G. Paun, E. Neagu, S. C. Litescu, P. Rotinberg and G. L. Radu, J. Serb. Chem. Soc., 2012, 77, 11911203.

39 E. Neagu, G. Paun, D. Constantin and G. L. Radu, Arab. J. Chem., 2013, DOI: 10.1016/j.arabjc.2013.09.028.

40 G. Paun, S. C. Litescu, E. Neagu, A. Tache and G. L. Radu, J. Enzyme Inhib. Med. Chem., 2014, 29, 28-34.

41 E. Pereira, L. Barros, R. C. Calhelha, M. Dueñas, A. M. Carvalho, C. Santos-Buelga and I. C. F. R. Ferreira, Food Funct., 2014, 5, 1848-1855.

42 F. Ferreres, A. Gil-Izquierdo, P. B. Andrade, P. Valentão and F. A. Tomás-Barberán, J. Chromatogr. A, 2007, 1161, 214223.

43 F. Ferreres, A. Gil-Izquierdo, J. Vinholes, C. Grosso, P. Valentão and P. B. Andrade, Rapid Commun. Mass Spectrom., 2011, 25, 700-712. 